\title{
Basic density and moisture content of coniferous branches and wood in Northern Norway
}

\author{
J. Dibdiakova ${ }^{1}$, K. Vadla ${ }^{1}$ \\ ${ }^{1}$ Norwegian Forest and Landscape Institute, Section Wood Technology, P.O.Box 115, NO-1431 Ås, \\ Norway
}

\begin{abstract}
With the increasing demand for fuel the use of biomass from other tree components like branches and tops has increased rapidly. Norway has abundant raw material resources which can be use for bioenergy. Sitka spruce and Norway spruce are becoming more interesting due to their potential energy for heating. The study consisted of 2 site locations in Nordland - 1 stand of Sitka spruce in Steigen area, and 1 stand of Sitka spruce, 1 stand of Norway spruce, and 1 stand of Lutz spruce in Sømna area. Bark thickness differed between the sites within decreasing pattern along the stem. Significant differences of bark density between sites, tree species and tree height levels with decreasing trend towards the top were found. Branches density decreased along the crown level and had about $15-20 \%$ higher density than wood density. Wood density varied significantly with sites and height of tree - highest pattern on the tree base, decreasing to $20 \%$ of height, and again increasing to the top. The moisture content of branches, wood and bark increased from the base of tree to the top. Bark moisture was about $20-25 \%$ higher as wood moisture content. Sitka spruce in Northland may be highly considered as a valuable bioenergy source.
\end{abstract}

\section{Introduction}

The biofuel market is not sufficiently studied and less evolved in Norway compared to what has already taken place in the neighboring countries of Sweden and Finland over the most recent years. In order to reach national goals, a sustainable utilization of forest biofuels is a central task also for Norway.

Traditionally it has been the tree stem which is used as an industrial raw material and an energy source. However, with the increasing demand for fuel the use of biomass from other tree components like branches and tops has increased rapidly. Approximately 6\% (16-17 TWh) of the total annual energy consumption in Norway comes from biomass. Norway has abundant raw material resources usable biomass potential can be doubled to 30-35 TWh per year [1]. Sitka spruce and Lutz spruce are important wood species from the view of economic use of forest in north part of Norway where they grow faster with the higher volume production that Norway spruce in this forest area [2]. These species are becoming more interesting due to their potential energy for heating. For potential industrial utilization of stem wood and branches the most important properties are the moisture content and density.

In our work we focused to obtain representative samples for the basic properties such as moisture content, basic density of trees from cultivated forests. Variations in quantity and various tree properties such as stem, branches and top volumes were also estimated. For this purpose tree 
variables such as crown length, and also stand variables (site quality, stand density, location etc.) were used to describe how the properties vary between the stands.

\section{Material and methods}

The study consists of 2 site locations in northern part of Norway (Nordland): 1 stand of Sitka spruce in Steigen $\left(67^{\circ} 79^{\prime} \mathrm{N} ; 1^{\circ} 33^{\prime} \mathrm{E}\right), 1$ stand of Sitka spruce in Sømna $\left(65^{\circ} 28^{\prime} \mathrm{N} ; 12^{\circ} 14^{\prime} \mathrm{E}\right), 1$ stand of Norway spruce in Sømna $\left(65^{\circ} 28^{\prime} \mathrm{N} ; 12^{\circ} 14^{\prime} \mathrm{E}\right)$, and 1 stand of Lutz spruce in Sømna $\left(65^{\circ} 28^{\prime} \mathrm{N}\right.$; $\left.12^{\circ} 14^{\prime} \mathrm{E}\right)$.

The representative area of each stand (radius $12 \mathrm{~m}$ ) was labelled, and 35-40 trees were registered with their diameter at breast height. Trees were grouped into 3 diameter classes, and one tree was selected for each diameter class. After these trees have been felled, their height $(\mathrm{m})$, diameter at breast height $(\mathrm{cm})$, crown length and bark thickness were measured. The age was recorded, Table 1 .

Table 1. Characteristics of the individual site locations (1 Steigen site; 2 Sømna site).

\begin{tabular}{|c|c|c|c|c|c|c|c|c|}
\hline Site & $\begin{array}{l}\text { Tree } \\
\text { species }\end{array}$ & $\begin{array}{c}\text { Site } \\
\text { index } \\
(\mathrm{m})\end{array}$ & $\begin{array}{l}\text { Height } \\
\text { (m) }\end{array}$ & $\begin{array}{l}\mathrm{DBH}^{\mathrm{a}} \\
(\mathrm{cm})\end{array}$ & $\begin{array}{l}\text { Crown } \\
\text { length } \\
(\mathrm{m})\end{array}$ & $\begin{array}{l}\text { Crown } \\
\text { ratio }^{\mathrm{b}}\end{array}$ & $\begin{array}{l}\text { Stand } \\
\text { age }\end{array}$ & $\begin{array}{c}\text { Ring } \\
\text { width } \\
(\mathrm{mm}) \\
\end{array}$ \\
\hline Steigen & $\begin{array}{l}\text { 1-Sitka } \\
\text { spruce }\end{array}$ & 17 & $\begin{array}{c}16.5 \\
(1.669)\end{array}$ & $\begin{array}{c}17.8 \\
(3.277)\end{array}$ & $\begin{array}{c}13.6 \\
(1.565)\end{array}$ & 0.96 & 42 & $\begin{array}{c}3.9 \\
(0.228)\end{array}$ \\
\hline Sømna & $\begin{array}{l}\text { 2-Norway } \\
\text { spruce }\end{array}$ & 14 & $\begin{array}{c}17.1 \\
(1.423)\end{array}$ & $\begin{array}{c}19.8 \\
(3.692)\end{array}$ & $\begin{array}{c}17.8 \\
(0.047)\end{array}$ & 0.98 & 43 & $\begin{array}{c}4.3 \\
(0.403)\end{array}$ \\
\hline Sømna & $\begin{array}{l}\text { 2-Sitka } \\
\text { spruce }\end{array}$ & 14 & $\begin{array}{c}20.7 \\
(2.332)\end{array}$ & $\begin{array}{c}23.2 \\
(4.676)\end{array}$ & $\begin{array}{c}18.5 \\
(1.027)\end{array}$ & 0.94 & 46 & $\begin{array}{c}2.8 \\
(0.192)\end{array}$ \\
\hline Sømna & $\begin{array}{l}\text { 2-Lutz } \\
\text { spruce }\end{array}$ & 14 & $\begin{array}{c}18.8 \\
(2.094)\end{array}$ & $\begin{array}{c}22.5 \\
(4.666)\end{array}$ & $\begin{array}{c}17.2 \\
(2.010)\end{array}$ & 0.94 & 43 & $\begin{array}{c}4.9 \\
(0.200)\end{array}$ \\
\hline
\end{tabular}

${ }^{a}$ Diameter at breast height $(\mathrm{cm}) ;{ }^{b}$ Crown length (m) of sample trees divided by tree height $(\mathrm{m})$.

Cross-sectional discs, $5 \mathrm{~cm}$ thick, were cut from each tree along the stem at different height levels (bottom, breast height, 20\%, 40\%,60\%, 80\%). Three branches, including the needles, from each tree were cut along different crown levels (lower, middle, top of the crown) and weighed fresh in the field, same as stem discs. All cut discs and branches were kept frozen prior to the measurement of moisture content and basic density in the laboratory.

Within the 2-Sitka spruce forest in Sømna we recorded the trees within the highest breast height diameter and the highest height, Figure 1.
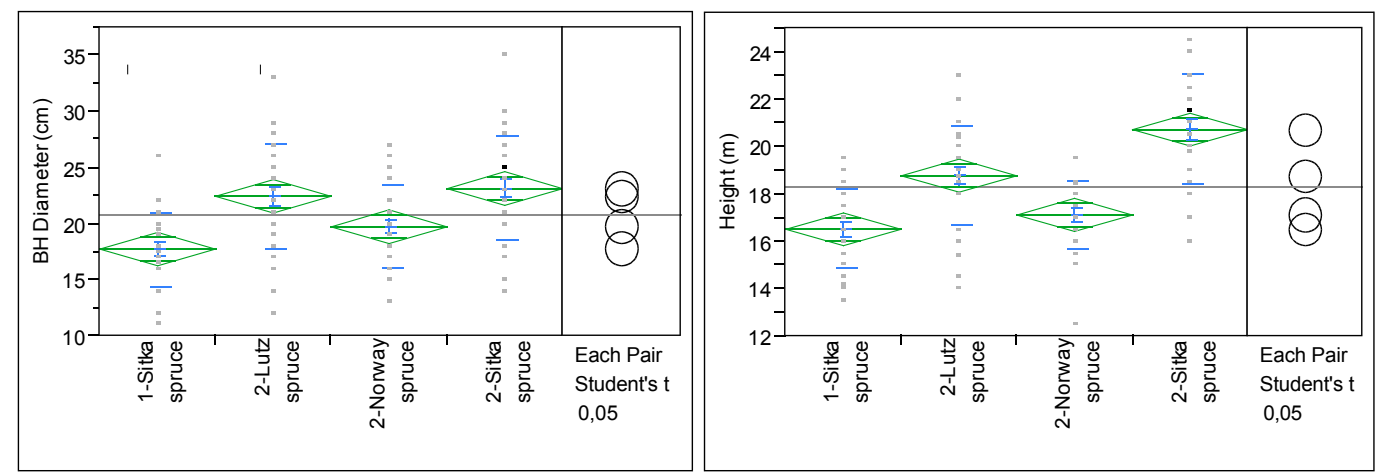

Fig.1 Distribution of the breast height diameters and the heights within the site locations (1 Steigen site; 2 Sømna site) and the tree species. 


\section{Results and discussions}

The most important part of this research was the investigation for differentiation of tree species coming from different site locations in Nordland. It was expected that if significant differences between properties could be observed, it should be possible to link these differences to the origin of the tree species. The following chapters provide the most important discoveries.

\subsection{Bark thickness}

The average bark thickness of Sitka spruce in Steigen decreased from $7.3 \mathrm{~mm}$ to $2.9 \mathrm{~mm}$, from 4.7 $\mathrm{mm}$ to $2.0 \mathrm{~mm}$ for Norway spruce in Sømna, from $5.6 \mathrm{~mm}$ to $3.0 \mathrm{~mm}$ for Sitka spruce in Sømna, and from $6.2 \mathrm{~mm}$ to $2.5 \mathrm{~mm}$ for Lutz spruce in Sømna. Tree-to-tree variations of bark thickness within a site in Steigen shows significantly higher difference than sites in Sømna, especially in the lower part of the stem, where coefficient of variation of the mean was approximately $15 \%$. Bark thickness decreased from the base to the top, and higher values were always found near the base of the tree.

\subsection{Bark content}

Bark content varied axially within the tree height and sites. The pattern was similar for all stands, the content being higher in the lower part of the stem, decreasing to the $35 \%$ height level and increasing again, but less, toward the top of the trees. Sitka spruce in Steigen has statistically significant difference $(p<0.001)$ compare to other tree species in Sømna, Figure 2.

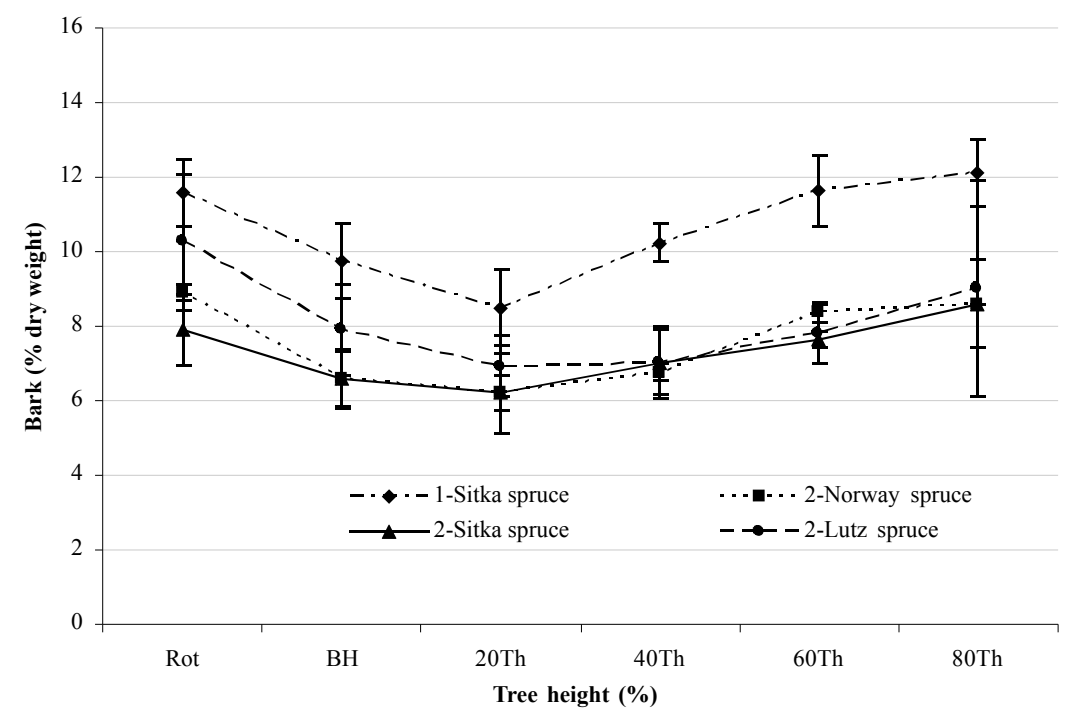

Fig. 2. Axial variations of bark content in the stem wood of tree species within individual site locations (1 Steigen site; 2 Sømna site). Mean values and standard deviations.

The variations of bark content are the combined effect of the differing rates of axial variation of bark thickness and wood diameter. Quilhó and Pereira [3] also observed for the eucalyptus wood a progressive decrease of bark percentage from the base to mid stem and then an increase towards the top. Guidi et al. [4] found with their work as diameter of wood increased total bark amount of stem also increased but relative amount of bark decreased. 


\subsection{Wood basic density}

The average wood basic density at breast height diameter was $428 \mathrm{~kg} / \mathrm{m}^{3}$ for Sitka spruce in Steigen, $417 \mathrm{~kg} / \mathrm{m}^{3}$ for Sitka spruce in Sømna, $373 \mathrm{~kg} / \mathrm{m}^{3}$ for Norway spruce in Sømna, and $331 \mathrm{~kg} / \mathrm{m}^{3}$ for Lutz spruce in Sømna. The anlysis of wood basic density showed highly significant differences between stands $\left(\mathrm{R}^{2}=0.94\right)$. Variations along the height of tree in each stand were found. The wood density was higher in the lower part of stems, decreasing to the $20 \%$ tree height and again slightly increasing to the top of trees. Generally, basic density increases with decreasing width of growth rings [5]. We found out the same trend. Sitka spruce in Sømna at breast height diameter had less wide annual rings $(2.8 \mathrm{~mm})$, Table 1 , and therefore highest basic density $\left(425 \mathrm{~kg} / \mathrm{m}^{3}\right)$. Compare to Lutz spruce in Sømna with the wider annual rings (4.9) basic density was significantly lower (339 $\left.\mathrm{kg} / \mathrm{m}^{3}\right)$.

\subsection{Bark density}

There was a significant difference of bark density between stands $(p<0.05)$. With each site, significant differences $(p<0.05)$ in bark density were found along the height levels. Highest densities were found near the base of trees and decreasing to the top. The bark density on base in all side locations was $5-10 \%$ heigher than the wood density on base. This fact was observed only on the base of trees.

\subsection{Branches basic density}

There were a significant differences of density between tree species along the crown level $\left(\mathrm{R}^{2}=0.34\right.$ for lower, $\mathrm{R}^{2}=0.93$ for middle, $\mathrm{R}^{2}=0.43$ for top level). Branches density of all tree species and stands varied along the crown level within the lowest density on the top crown level, Table 2.

Table 2. Basic density of branches within crown level $\left(\mathrm{kg} / \mathrm{m}^{3}\right)$, mean values and standard deviations, (1 Steigen site; 2 Sømna site).

\begin{tabular}{llccc}
\hline Site & Tree species & Bottom & Middle & Top \\
\hline Steigen & 1-Sitka spruce & $512.9(70.6)$ & $499.9(39.7)$ & $471.2(38.3)$ \\
Sømna & 2-Norway spruce & $504.1(20.4)$ & $486.6(20.5)$ & $461.1(29.5)$ \\
Sømna & 2-Sitka spruce & $539.4(37.1)$ & $503.7(39.5)$ & $492.3(19.6)$ \\
Sømna & 2-Lutz spruce & $519.0(33.3)$ & $500.9(31.7)$ & $475.7(33.5)$ \\
\hline
\end{tabular}

Lower crown branches had $8-9 \%$ higher basic density than the upper one at the significant level in all tree species. Trendelenburg [6] already stated that the density of dry spruce branch wood can be twice as high as stem wood density. The data by Gryc and Horáček [7] showed that the branch wood had a higher basic density than stem wood; the difference between these two densities was 88-218 $\mathrm{kg} / \mathrm{m}^{3}$.

\subsection{Wood moisture content}

At a given stem height the proportion of live tissues and sapwood in a tree biomass increase from stem base to top, resulting in an increaseing moisture content of wood [8]. The average moisture content for each location and tree species increased from the base of trees (42\%) to the top of trees $(55 \%)$, within significantly greater variations $\left(\mathrm{R}^{2}=0.89\right)$ on the base of trees than variations on the top of trees $\left(\mathrm{R}^{2}=0.56\right)$. The stand location was a significant factor for moisture content, and the tree height level having even greater significance. 


\subsection{Bark moisture content}

The average moisture content of bark was higher than the average wood moisture content with increasing patterns from the base $(50 \%)$ to the top of trees $(65 \%)$. The significant differences of bark moisture content between different locations and height of trees were found $(p<0.05)$.

\subsection{Branches moisture content}

Hakkila [8] reported that the differences in the moisture content of branches are partly results of differences in the basic density of branches. Significant differences $(p<0.05)$ of branches moisture content were found between the tree species in individual side locations, Table 3.

Table 3. Moisture content of branches within crown level (\%), mean values and standard deviations, (1 Steigen site; 2 Sømna site).

\begin{tabular}{llccc}
\hline Site & Tree species & Bottom & Middle & Top \\
\hline Steigen & 1-Sitka spruce & $50.0(3.3)$ & $49.9(2.9)$ & $52.6(1.6)$ \\
Sømna & 2-Norway spruce & $41.1(2.6)$ & $39.8(2.2)$ & $45.4(2.0)$ \\
Sømna & 2-Sitka spruce & $45.2(2.9)$ & $45.8(2.6)$ & $46.1(2.4)$ \\
Sømna & 2-Lutz spruce & $43.9(2.8)$ & $45.9(2.2)$ & $47.7(2.5)$ \\
\hline
\end{tabular}

The average moisture content of branches had increasing trend from the base $(45 \%)$ to the top of trees $(50 \%)$. The moisture content slightly varied along the crown lewel $\left(\mathrm{R}^{2}=0.24\right.$ for lower, $\mathrm{R}^{2}=0.12$ for middle, $\mathrm{R}^{2}=0.31$ for top crown level).

\section{Conclusions}

Bark thickness differed between the site locations within decreasing pattern along the stem. Sitka spruce in Steigen had significantly higher bark thickness and bark content. Significant differences of bark density between sites, tree species and tree height levels $(p<0.005)$ with decreasing trend towards the top were found. Densest bark was found for Sitka spruce in Sømna. Branches density decreased along the crown level and had about $15-20 \%$ higher density than wood density. Norway spruce branches in Sømna were less dense. Wood density varied significantly with site locations and height of trees - highest pattern on the tree base, decreasing to $20 \%$ of height, and again increasing to the top. Lutz and Norway spruce in Sømna had lower density. The moisture content of branches, wood and bark increased from the base of tree to the top. Bark moisture was about $20-25 \%$ higher as wood moisture. Sitka spruce in Sømna had lowest bark and wood moisture content than other tree species. Highest moisture content of branches was found for Sitka spruce in Steigen.

Sitka spruce in Sømna had lower bark content, lower bark thickness, higher wood, bark and branches basic density and lower moisture content of wood, bark and branches compare to Sitka spruce in Steigen.

Norway spruce in Sømna had significantly lower qualitative and quantitative properties unlike other tree species.

Obtained values for Sitka spruce in Nordland may be highly considered as a valuable biomass source for bioenergy.

\section{Acknowledgements}

The financial support was given by Forest Power project grouping the Norwegian, Swedish and Finland partners. The authors would like to thank to forest managers Steinar Pedersen to help us with the field work in Sømna forest site and Gjermund Laxaa for help with the sites in Steigen forest. In addition authors wish to acknowledge Tore Filbakk for his help with field work; Thor-Erik V. Alstad 
and Kari Hollung for preparing samples, all of them from Norwegian Forest and Landscape Institute in Ås.

\section{References}

1. P. Hakkila, Folia Forestalia 773, Hakkuupoistuman Latvusmassa, (Crown mass of trees at the harvesting phase), (In Finnish), 1-24, (1991)

2. T. Johansson, Silva Fennica 33 (4), Biomass production of Norway Spruce (Picea abies (L.) Karst.) Growing on Abandoned Farmland, 261-280, (1999)

3. T. Quilhó, H. Pereira, Iawa Journal 22 (3), Within and between-tree variation of bark content and wood density of Eucalyptus Globulus in commercial plantations, 255-256, (2001)

4. W. Guidi, E. Piccioni, M. Ginanmi, E. Bonari, Biomass and Bioenergy 32, Bark content estimation in poplar (Populus deltoids L.) short-rotation coppice in Central Italy, 518-524, (2008)

5. J.P. Skovsgaard, C. Bald, T. Nord-Larsen, Scandinavian Journal of Forest Research 26, Functions for biomass and basic density of stem crown and root system of Norway spruce (Picea abies (L.) Karst.) in Denmark, 3-20, (2011)

6. R. Trendelenburg, Das Holz als Rohstoff (Lehmans Verlag, München, Berlin, 1959)

7. V. Gryc, P. Horáček, Journal of Forest Science 53, Variability in density of spruce (Picea abies (L.) Karst.) wood with the presence of reaction wood, 129-137 (2007)

8. P. Hakkila, Utilization of residual forest biomass (Springer-Verlag, Helsinki, 1989) 